Agata Łysakowska-Trzoss

(Uniwersytet im. Adama Mickiewicza w Poznaniu)

mgr, aklysakowska@gmail.com

ORCID iD: 0000-0001-8065-5645

\title{
"Ani jedna taśma filmowa nie może ulec zniszczeniu". Osiemdziesiąt lat działalności Międzynarodowej Federacji Archiwów Filmowych
}

\section{Wstęp}

Idea ochrony dziedzictwa filmowego zrodziła się niemal równocześnie z pojawieniem się nowego medium, jakim było kino. Postulat dotyczący stworzenia miejsca, które zapewni przechowywanie, opracowanie, konserwacje czy wreszcie udostępnianie materiałów audiowizualnych, podnosiło na przełomie XIX i XX w. wielu Polaków - wśród nich byli m.in.: Władysław Umiński, Bolesław Matuszewski, Bolesław Prus czy Zygmunt Korosteński. Matuszewski pisał w 1898 r.: "Chodzi o to, by temu być może uprzywilejowanemu źródłu historii nadać ten sam autorytet, ten sam oficjalny byt i uprzystępnić je - podobnie jak to się dzieje z innymi znanymi dotąd archiwami"1.

Szczególnie w pierwszym okresie swojego istnienia taśmy filmowe narażone były na zniszczenia. Ze względu na budowę z nitrocelulozowej błony często ulegały pożarom. Nie ratowano także taśm, których nie strawił ogień - wielokrotnie użytkowane, po zdjęciu wierzchniej warstwy były ponownie wykorzystywane do produkcji następnych filmów. Odzyskiwano także srebro, będące jednym ze składników światłoczułej emulsji, którą powlekano taśmy. Masowe niszczenie taśm trwało od 1912 r., a szczególnym momentem okazał się przełom dźwiękowy - uznano wówczas nieme filmy za niewarte zachowania. Na pomoc cennym taśmom ruszył w tym momencie Henri Langlois, organizator klubu filmowego Cercle du Cinéma oraz

\footnotetext{
${ }^{1}$ M. Henrykowski, Film jako źródło historyczne, Poznań 2000, s. 13-14.
} 
współzałożyciel i dyrektor Cinémathèque Française². W 1937 r. Langois opublikował w „La Cinématographie Française” artykuł, w którym podsumował rozwój archiwów filmowych ${ }^{3}$ oraz podkreślił znaczenie współpracy między tymi instytucjami, zaznaczając, że takie działanie przyczyni się to do poznania „prawdziwej historii kina”"

\section{Początki FIAF}

Jednym z pierwszych kroków do zacieśnienia współpracy między poszczególnymi archiwami filmowymi było przekazanie Langois przez Museum of Modern Art w Nowym Jorku kopii filmu Georges'a Méliès'a z 1902 r. Le Voyage dans la Lune (Podróż na księżyc). Do podobnej współpracy doszło także między Cinémathèque Française a British Film Institute ${ }^{5}$. Inicjatywa ta okazała się jedną z podwalin pod utworzenie Międzynarodowej Federacji Archiwów Filmowych (Fédération Internationale des Archives du Film FIAF). Wymiana materiałów audiowizualnych była niezwykle ważnym elementem misji FIAF, tak samo, jak stwierdzenie Langois, że „ani jedna taśma filmowa nie może ulec zniszczeniu" ${ }^{\prime \prime}$.

Założycielskie spotkania Federacji odbyły się w czerwcu 1938 r. w paryskim hotelu Chatam. Wzięli w nich udział: Henri Langois i Georges Franju z Francji (reprezentujący Cinémathèque Française), Frank Hensel z Niemiec (Reichsfilmarchiv), John Abbott z USA (Museum of Modern Art Film Library) oraz Olwen Vaughan z Wielkiej Brytanii (National Film Library) ${ }^{7} .17$ czerw-

${ }^{2}$ Langois założył Cinémathèque Française wraz z Georges Franju w 1936 r. Przez lata Cinémathèque stała się istotnym ośrodkiem filmowym - stąd wywodzili się twórcy la Nouvelle Vague, Francuskiej Nowej Fali, tacy jak Alain Resnais, François Truffaut, czy nagrodzeni przez FIAF za ochronę dziedzictwa filmowego Agnes Varda i Jean-Luc Godard. W 1968 r. odwołanie Langois z funkcji dyrektora Cinémathèque stało się przyczyną manifestacji studenckich.

${ }^{3}$ W momencie publikacji artykułu Langois istniały m.in.: National Film Archive w Londynie (utworzone w 1935 r.), kolekcja filmowa w Museum of Modern Art w Nowym Jorku (1935) czy Reichsfilmarchiv w Berlinie (którego początki sięgają 1934 r.). Od 1933 r. funkcjonowało archiwum filmowe w Sztokholmie. Warto zaznaczyć, że w 1935 r. odbył się w Berlinie Międzynarodowy Kongres Filmowy, podczas którego jedna z komisji obradowała na temat konieczności archiwizacji materiałów audiowizualnych.

${ }^{4}$ Ch. Dupin, First Tango in Paris: The Birth of FIAF, 1936-1938, "Journal of Film Preservation" 2013, nr 88, s. 43.

${ }^{5}$ Ch. Dupin, The Origins of FIAF, 1936-1938, https://www.fiafnet.org/pages/History/ Origins-of-FIAF.html (dostęp: 20.03.2019).

${ }^{6}$ R. Nowicki, Międzynarodowy Kongres Archiwów Filmowych w Warszawie, "Archeion” 1956, t. 26, s. 261-263.

${ }^{7}$ Minutes of the first meeting of the founder-members, 9 June 1938, Paris, Minutes of the second meeting of the founder-members, 15 June 1938, Paris. Dokumenty z pierwszych spotkań komitetu założycielskiego FIAF dostępne są na stronie FIAF Archive: Digitized Archival Documents, 
ca podpisano Porozumienie Międzynarodowej Federacji Archiwów Filmowych (Agreement for the International Federation of Film Archives). Pierwszym prezydentem Federacji został John Abott (1938-1939), a po nim funkcję tę przejął Frank Hensel.

W 1939 r., w nowojorskim Museum of Modern Art, odbył się pierwszy Kongres, na który przybyło dwudziestu przedstawicieli z instytucji z całego świata (m.in. Japonii, Argentyny i Chile). Należy przy tym zaznaczyć, że oprócz osób związanych $\mathrm{z}$ archiwizowaniem materiałów audiowizualnych pojawili się także ludzie pracujący przy wystawach światowych (byli to delegaci m.in. ze Szwajcarii i Danii) bądź zajmujący się szeroko pojętą administracją (z Buenos Aires na Kongres przyjechał sekretarz ambasady Stanów Zjednoczonych $)^{8}$.

Rozwój Federacji zastopował wybuch II wojny światowej - do działania FIAF powróciła w 1946 r. Według broszury z roku 1958, organizacja liczyła trzydziestu członków ${ }^{9}$. Obecnie Federacja liczy 89 aktywnych członków (w tym polską Filmotekę Narodową - Instytut Audiowizualny) ${ }^{10}$ oraz 75 członów stowarzyszonych (w tym Filmoteka Śląska z siedzibą w Katowicach $)^{11}$.

\section{Cele i struktura Federacji}

Jako cele statutowe FIAF traktuje: wspieranie działań mających na celu gromadzenie i ochronę filmów, które stanowią dzieła sztuki lub dokumenty historyczne; ułatwianie gromadzenia i ochrony wszelkiego rodzaju dokumentacji filmowej; zachęcanie państw do tworzenia i rozwijania archiwów filmowych mających za zadanie ochronę narodowego i międzynarodowego dziedzictwa filmowego, a także zrzeszanie tych archiwów; rozwijanie współpracy pomiędzy członkami federacji oraz zapewnienie możliwości dostępu do filmów i dokumentów w wymiarze międzynarodowym; promowanie sztuki i kultu-

https://www.fiafnet.org/pages/History/Digitised-Documents.html (dostęp: 20.04.2019). Wbrew temu, co pisze Hendrykowski w swojej pracy Film jako źródło historyczne (s. 16), wśród założycieli nie było przedstawicieli archiwum filmowego z Wszechzwiązkowego Państwowego Instytutu Kinematografii z siedzibą w Moskwie.

${ }^{8}$ FIAF Congresses 1939 New York, 25-26 July 1939, https://www.fiafnet.org/images/ti nyUpload/History/FIAF-Archives/Digitized \%20docs/Congresses/19390725\%20New \% 20 York\%20Congress_Minutes\%20Day\%201_EN.pdf (dostęp: 3.05.2019).

${ }^{9}$ FIAF 1938-1958, https://www.fiafnet.org/images/tinyUpload/Publications/FIAFBookshop/1958\%20FIAF\%20Brochure.pdf, s. 5 (dostęp: 20.03.2019).

${ }^{10}$ FIAF Members, https://www.fiafnet.org/pages/Community/Members.html (dostęp: 18.04.2019).

${ }^{11}$ FIAF Associates, https://www.fiafnet.org/pages/Community/Associates.html (dostęp: 18.04.2019). 
ry filmowej oraz zachęcanie do prowadzenia badań historycznych w dziedzinie kultury filmowej ${ }^{12}$.

Władzami FIAF są Komitet Wykonawczy oraz Walne Zgromadzenie ${ }^{13}$. W skład Federacji wchodzą członkowie oraz członkowie stowarzyszeni. W myśl statutu członkami są instytucje, do których kompetencji należy ochrona zbiorów filmowych, które posiadają środki stosowne do realizacji tego zadania i które podpiszą kodeks etyczny FIAF (tym samym są związane z jego postanowieniami). Członków zachęca się do: organizowania projekcji i pokazów filmowych przy użyciu kopii filmowych wykonanych specjalnie do tego celu, udostępniania zbiorów dokumentacyjnych; gromadzenia i organizowania wystaw zabytków sztuki filmowej; publikowania literatury filmowej oraz prowadzenia szeroko pojętej działalności non profit, związanej z promowaniem i rozpowszechnianiem kultury filmowej z punktu widzenia historycznego, edukacyjnego, artystycznego ${ }^{14}$. Natomiast członkami stowarzyszonymi są instytucje prowadzące działalność związaną z celami Federacji, które nie zajmują się samodzielnym gromadzeniem filmów i które podpiszą kodeks etyczny FIAF ${ }^{15}$.

W skład Federacji wchodzą także trzy specjalistyczne komisje: Komisja Techniczna (Technical Commission), Komisja Katalogowania i Dokumentacji (The Cataloguing and Documentation Commission) oraz Komisja Programowania i Dostępu do Zbiorów (Programming and Access to Collections Commission). Współpracują w nich specjaliści z archiwów należących do FIAF, a każda z komisji odpowiada za przygotowanie warsztatów podczas corocznego Kongresu FIAF'16.

Według Statutu, FIAF pozyskuje fundusze poprzez: roczne składki członkowskie, zwrot wydatków lub dodatkowe składki członkowskie od członków stowarzyszonych, przeznaczone na specjalne cele określone przez Walne Zgromadzenie; kwoty stanowiące zwrot wydatków stron trzecich za wykonane usługi, środki uzyskane $z$ organizacji imprez, inne dochody wynikające $\mathrm{z}$ działalności Federacji oraz dotacje i darowizny ${ }^{17}$.

Federacja zarejestrowana jest we Francji, jednak swoją siedzibę ma w Belgii, a sam sekretariat FIAF mieści się w Brukseli. Jest to miejsce szczególne dla historyka filmu, gdyż znaleźć w nim można wiele dokumentów opisujących działalność organizacji od lat trzydziestych XX w. FIAF stara się digita-

\footnotetext{
${ }^{12}$ Statut FIAF zamieszczony na stronie Filmoteki Narodowej, http://www.fn.org.pl/public/upload/STATUT_FIAF__III_26069_br_1.pdf, s. 1 (dostęp: 18.03.2019).

13 Tamże, s. 3.

14 Tamże, s. 1-2.

15 Tamże, s. 2.

${ }^{16}$ FIAF Commissions, https://www.fiafnet.org/pages/Community/Commissions.html (dostęp: 22.04.2019).

${ }^{17}$ Statut FIAF, s. 6.
} 
lizować zasób własnego archiwum i udostępniać go na swojej stronie internetowej. Wśród dokumentacji obecnej na witrynie internetowej znaleźć można m.in.: sprawozdania z kongresów, pierwsze biuletyny FIAF, listy członków, broszury oraz publikacje ${ }^{18}$.

\section{Kongresy}

Federacja stara się koordynować współpracę między archiwami na całym świecie. Jednym z najważniejszych wydarzeń, podczas których osoby związane z dziedzictwem filmowym mogą wymienić się doświadczeniami, są organizowane przez FIAF kongresy. Pierwsze trzy odbyły się w: Nowym Jorku (1939), Paryżu (1946) i Kopenhadze (1949), natomiast następne organizowane były już corocznie. W kwietniu 2019 r. kongres miał miejsce w szwajcarskiej Lozannie. Motywami kongresów są zarówno tematy związane z trendami panującymi w sztuce filmowej (np. podczas kongresu w Karlovych Varach dyskutowano o powojennej animacji, a w 2002 r. Seulu - na temat szeroko pojętego kina azjatyckiego), jak i problemami charakterystycznymi dla archiwów filmowych (w 1972 r. w Bukareszcie temat przewodni brzmiał Archiwa filmowe i badania historyczne, a w 2006 r. Sao Paulo - Przyszłość archiwów filmowych $w$ świecie kina cyfrowego $)^{19}$. Kongresy mogą być także polem do przedstawienia działalności poszczególnych członków Federacji - w 2016 r. w Bolonii Filmoteka Narodowa miała możliwość pochwalenia się odrestaurowanymi cyfrowo filmami animowanymi dla dzieci ze studia Małych Form Filmowych Se-Ma-For ${ }^{20}$.

Warto w tym miejscu nadmienić, że w 1955 r. kongres odbył się w Warszawie. Obrady miały miejsce w sali obrad Polskiej Akademii Nauk w Pałacu Kultury i Nauki. W czasie kongresu przedstawiciele państw-członków składali sprawozdania $\mathrm{z}$ rocznej działalności archiwów filmowych, delegaci rozmawiali m.in. na temat usamodzielnienia się archiwów filmowych - i tak np. reprezentant Wielkiej Brytanii podkreślał coraz większą autonomię Narodowego Archiwum Filmowego wobec Brytyjskiego Instytutu Filmowego. Z kolei prof. Lebiediew przedstawił historię filmu radzieckiego i instytucji kierujących produkcją i przechowywaniem filmów. Funkcję pre-

${ }^{18}$ FIAF Archive: Digitized Archival Documents, https://www.fiafnet.org/pages/History/ Digitised-Documents.html (dostęp: 20.04.2019).

${ }^{19}$ Past FIAF Confressess, https://www.fiafnet.org/pages/Events/Past-Congresses.html (dostęp: 15.04.2019).

${ }^{20}$ Filmoteka Narodowa na 72. Kongresie FIAF i 30. edycji festiwalu Il Cinema Ritrovato w Bolonii, http://www.fn.org.pl/pl/news/info/61/filmoteka-narodowa-na-72-kongresie-fiaf-i-30-edy cji-festiwalu-il-cinema-ritrovato-w-bolonii.html (dostęp: 5.05.2019). 
zesa FIAF pełnił wówczas Jerzy Toeplitz ${ }^{21}$. Piszący sprawozdanie dla czasopisma "Archeion” Romuald Nowicki zauważył wówczas, że organizacja archiwistyki filmowej jest w Polsce stosunkowo młoda - wspominał on w swoich rozważaniach na ten temat dwie polskie placówki tego typu, mianowicie archiwum filmowe przy Wyższej Szkole Filmowej w Łodzi oraz utworzone w kwietniu 1955 r. Centralne Archiwum Filmowe, które zostało powołane w ramach Centralnego Urzędu Kinematografii ${ }^{22}$.

\section{Działalność wydawnicza}

FIAF prowadzi także działalność wydawniczą, m.in. w 1980 r. opublikowała podręcznik A Handbook for Film Archives ${ }^{23}$. Wśród popularnych wydawnictw z zakresu działalności Federacji wymienić należy także: FIAF Digital Projection Guide ${ }^{24}$, The Advanced Projection Manual, The FIAF Moving Image Cataloguing Manual czy This Film is Dangerous - A Celebration of Nitrate Film ${ }^{25}$.

Istotnym polem działalności FIAF jest piśmiennictwo dotyczące ochrony i upowszechniania dziedzictwa filmowego. Pierwszą próbę podjęto już w 1955 r., kiedy zaczęto wydawać „FIAF News Bulletin” (który wychodził do 1963 r. $)^{26}$. W październiku 2011 r. pojawił się pierwszy numer „FIAF Bulletin online", który wydawany jest co pół roku i jest dostępny na stronie internetowej Federacji27. Popularnym czasopismem jest również „The Journal of Film Preservation”, który początkowo ukazywał się jako „FIAF Information Bulletin” (od 1972 r.; jego nazwę zmieniono w 1993 r.). „The Journal of Film Preservation”, podobnie jak „FIAF Bulletin online”, wydawany jest co pół ro$\mathrm{ku}^{28}$.

Istotną aktywnością na polu popularyzacji działalności archiwów filmowych jest także prowadzenie przez FIAF baz danych, które reklamowane jest jako „podstawowe narzędzie dla każdego badacza filmu”. Wśród prowadzonych przez FIAF baz znajdują się: „Międzynarodowy indeks czaso-

${ }^{21}$ Według informacji ze strony Federacji, Jerzy Toeplitz pełnił tę funkcję w latach 19461972, Past FIAF Presidents Past FIAF Presidents (dostęp: 3.05.2019).

${ }^{22}$ R. Nowicki, Międzynarodowy Kongres Archiwów Filmowych w Warszawie, "Archeion” 1956, t. 26, s. 261-263.

${ }^{23}$ E. Bowser, J. Kulper, A handbook for film archives, Brussels 1980.

${ }^{24}$ T. Saetervadet, FIAF Digital Projection Guide, Bruxelles 2012.

${ }^{25}$ R. Smither, C.A. Surowiec, This Film is Dangerous - A Celebration of Nitrate Film, Bruxelles 2002.

${ }^{26}$ T. Saetervadet, The Advanced Projection Manual, Bruxelles 2006.

${ }^{27}$ FBO Archive, https://www.fiafnet.org/pages/Publications/FBO-Archive.html (dostęp: 5.05.2019).

28 "Journal of Film Preservation", https://www.fiafnet.org/pages/Publications/Aboutthe-JFP.html (dostęp: 10.04.2019). 
pism filmowych" („International Index to Film Periodicals”), który zawiera prawie czterysta tys. rekordów z 360 czasopism i wciąż jest aktualizowany; "Międzynarodowy indeks czasopism telewizyjnych” („International Index to Television Periodicals"), zawierający pięćdziesiąt tys. rekordów z lat 19792000, oraz baza "Skarby z archiwum filmowego" ("Treasures from the Film Archives"), która gromadzi informacje na temat niemych filmów z 112 archiwów filmowych ${ }^{29}$.

\section{Programy}

Federacja realizuje The FIAF Training and Outreach Program. Głównym założeniem programu było sprostanie światowym potrzebom w zakresie edukacji, archiwizacji, zarządzania, zabezpieczenia, digitalizacji oraz udostępniania materiałów filmowych ${ }^{30}$. W jego ramach organizowane są szkoły letnie i zimowe, seminaria oraz warsztaty ${ }^{31}$. Jednym z najważniejszych osiągnięć FIAF $\mathrm{w}$ dziedzinie popularyzacji archiwistyki filmowej jest Letnia Szkoła FIAF, której idea zrodziła się już w 1973 r. Od 2007 r. Letnia Szkoła organizowana jest we Bolonii i składa się z trzech etapów. Pierwszy z nich polega na samodzielnej nauce; w czasie drugiego etapu słuchacze uczestniczą $\mathrm{w}$ festiwalu Cinema Ritrovato, podczas którego biorą udział w pokazach, lekcjach i spotkaniach dotyczących konserwacji filmu. Ostatnim etapem są warsztaty w pracowni Immagine Ritrovata, podczas których uczestnicy Szkoły Letniej odbywają praktyki w rekonstrukcji fotochemicznej, dźwiękowej i cyfrowej32.

Flagowym programem FIAF, który skierowany został do archiwów Ameryki Łacińskiej i Południowej, był Escuela sobre ruedas (którego nazwa „Szkoła na kółkach" - nawiązuje do mobilności pracujących przy projekcie archiwistów). W ramach tego projektu specjaliści z zakresu ochrony i konserwacji zbiorów filmowych organizowali warsztaty oraz kursy dotyczące zachowania dziedzictwa audiowizualnego. Pomysł ten zrodził się już w 2002 r., natomiast realny kształt przybrał rok później, po Letniej Szkole w Rochester. Podczas gdy Letnie Szkoły FIAF koncentrowały się wokół ogólnych tematów, Projekt Escuela sobre ruedas miał odpowiadać na potrzeby konkretnych archiwów. Wzięły w nim udział organizacje głównie z Ameryki Łacińskiej, m.in.:

${ }^{29}$ FIAF Databases, https://www.fiafnet.org/pages/Publications/About-FIAF-Databases. html (dostęp: 10.04.2019).

${ }^{30}$ FIAF Training Outreach Programme, https://www.fiafnet.org/pages/Training/FIAFTraining-Outreach-Programme.html (dostęp: 5.05.2019).

${ }^{31}$ Past Events Organized or Supported by the FIAF Training \& Outreach Programme, https:/ / www.fiafnet.org/pages/Training/Past-Training-Outreach-Events.html (dostęp: 10.04.2019).

${ }_{32}$ About the FIAF Summer School, https://www.fiafnet.org/pages/Training/About-theFIAF-Summer-School.html (dostęp: 10.04.2019). 
z Meksyku, Nikaragui, Gwatemali, Argentyny, Chile, Brazylii. Wsparcie finansowe udało się uzyskać z programu Ibermedia ${ }^{33}$. Ostatnim spotkaniem $\mathrm{w}$ ramach tego cyklu były warsztaty przeprowadzone w meksykańskiej Filmotece UNAM w 2015 r. ${ }^{34}$

Podobnym projektem, pomagającym rozwijać archiwa filmowe, był The Film Archives in Africa ${ }^{35}$ - efekt współpracy między Goethe Institut Südafrika i FIAF. Program ten realizowany był w latach 2010-2015, a udział w nim wzięło pięć placówek mieszczących się w Kenii, Ghanie i Tanzanii. Podczas trwania programu udzielano archiwom finansowego wsparcia, zorganizowano kongres FIAF w Pretorii oraz Szkołę Letnią. Dla Kenya National Archive and Documentation Service w Nairobi zakupiono stół montażowy. Dwukrotnie także miały miejsce warsztaty w ramach "Szkoły na kółkach” - w Akrze (Ghana) oraz w Nairobi (Kenia). Koordynatorka projektu Eva Orbanz podsumowała go słowami: „Po zakończeniu projektu można wyciągnąć dwa wnioski. Z jednej strony był to wielki sukces $-\mathrm{z}$ drugiej strony ujawnił pilną potrzebę dalszego, ciągłego wsparcia" 36 .

Od 2013 r. funkcjonuje także FIAF Supporters Programme - program partnerski, który pozwala firmom, organizacjom non profit oraz podmiotom prywatnym wesprzeć działania Federacji. Osoby i instytucje uczestniczące w programie zobowiązują się wpłacać coroczną darowiznę, a w zamian otrzymują szereg benefitów (np. „Journal of Film Preservation” na maila czy zniżkę na publikacje wydawane przed FIAF w formie papierowej). W marcu $2019 \mathrm{r}$. w programie uczestniczyło 55 partnerów (37 firm, dwanaście organizacji non profit oraz sześć osób prywatnych) ${ }^{37}$.

${ }^{33}$ Program Ibermedia został zatwierdzony w 1996 r. podczas spotkania przedstawicieli państw z Ameryki Łacińskiej. Do inicjatywy przyłączyło się 21 krajów, w tym: Argentyna, Boliwia, Brazylia, Kolumbia, Kostaryka, Kuba, Chile, Ekwador, Hiszpania, Gwatemala, Włochy, Meksyk, Nikaragua, Panama, Paragwaj, Peru, Portugalia, Puerto Rico, Dominikana, Urugwaj i Wenezuela. Program promuje współpracę między tymi krajami w produkcji filmów fabularnych i dokumentalnych. Więcej na temat programu: http://www.programaibermedia.com/elprograma/ (dostęp: 1.05.2019).

${ }^{34}$ Taller Teórico-Practico de restauración fotoquimica y digital de película cinematográfica, https:/ / www.fiafnet.org/images/tinyUpload/Training/Forthcoming-FIAF-training/TemarioTaller\%20UNAM-11-2015.pdf (dostęp: 1.05.2019).

${ }^{35}$ E. Orbanz, Raport Film Archives in Africa, https://www.fiafnet.org/images/tinyUp load/Training/Film-Archives-in-Africa/Film\%20Archives \%20in \%20Africa \%20-\%20Final\%20 Report\%20English\%20-\%20July\%202015.pdf (dostęp: 17.04.2019).

${ }^{36}$ Film Archives in Africa. A joint project between the Goethe Institute, Johannesburg and the International Federation of Film Archives (FIAF) Final Report, https://www.fiafnet.org/ images/tinyUpload/Training/Film-Archives-in-Africa/Film\%20Archives\%20in\%20Africa \% 20 -\%20Final\%20Report\%20English\%20-\%20July\%202015.pdf (dostęp: 19.04.2019).

${ }^{37}$ FIAF Supporters Partnership Programme, https://www.fiafnet.org/images/tiny Upload/2019/03/FIAF-SUPPORTERS_BROCHURE-03-2019.pdf; https://www.fiafnet.org/pa ges/Community/FIAF-Supporters.html (dostęp: 4.05.2019). 


\section{Uhonorowanie zasług}

Ważnym elementem działalności Federacji jest także uznanie zasług osób, które przyczyniały się do zachowania dziedzictwa filmowego. Od 2001 r. FIAF przyznaje własne nagrody dla osób związanych ze światem kinematografii, których doświadczenia i osobiste zaangażowanie są zbieżne $\mathrm{z}$ ideami reprezentowanymi przez Federację. Pierwszym nagrodzonym był Martin Scorsese, a kolejne nagrody otrzymali: Manoel de Oliveira (2002), Ingmar Bergman (2003), Geraldine Chaplin (2004), Mike Leigh (2005), Hou Hsiao-hsien (2006), Peter Bogdanovich (2007), Nelson Pereira dos Santos (2008), Rithy Panh (2009), Liv Ullmann (2010), Kyoko Kagawa (2011), Agnès Varda (2013), Jan Švankmajer (2014), Yervant Gianikian i Angela Ricci Lucchi (2015), Jean-Pierre i Luc Dardenne (2016), Christopher Nolan (2017) i Apichatpong Weerasethakul (2018) ${ }^{38}$. Podczas kongresu w Lozannie w 2019 r. nagroda trafiła do Jean-Luca Godarda. Frédéric Maire, prezes FIAF, dyrektor Cinémathèque Suisse i były szef festiwalu filmowego w Locarno, uzasadnił werdykt, podkreślając ogromną wiedzę reżysera z zakresu historii filmu oraz jego wieloletnie związki z Cinémathèque Française i współpracę z Henrim Langois'em ${ }^{39}$.

FIAF prowadził także projekt FIAF Oral History Interviews, podczas którego przeprowadzono dwanaście wywiadów z osobami zasłużonymi dla zachowania dziedzictwa filmowego (m.in. z Lią van Leer - założycielką Haifa Cinematheque i Izraelskiego Instytutu Filmowego). Wywiady te były publikowane częściowo w "Journal od Film Preservation", dostępne są także na stornie internetowej Federacji. Osoby zasłużone dla FIAF mogą otrzymać jej honorowe członkostwo - wśród wyróżnionych tym tytułem znalazł się Jerzy Toeplitz $^{40}$.

\section{Zakończenie}

W 2018 r. Federacja obchodziła swoje osiemdziesiąte urodziny. Trudno nie zauważyć jej zasług na rzecz ochrony dziedzictwa audiowizualnego - misji, która przyświecała Federacji już od pierwszych lat jej istnienia.

FIAF angażuje się nie tylko w opiekę nad archiwami filmowymi, ale także popularyzację wiedzy na ten temat oraz kształcenie w zakresie archiwi-

${ }^{38}$ FIAF Award Recipients So Far..., https://www.fiafnet.org/pages/Events/PreviousAwards.html (dostęp: 4.05.2019).

${ }^{39}$ C. Roth, 2019 FIAF Award presented to Jean-Luc Godard, https:/ /www.fiafnet.org/pages/ Events/2019-FIAF-Award-JLG.html (dostęp: 19.04.2019).

${ }^{40}$ FIAF Honorary Members, https://www.fiafnet.org/pages/Community/HonoraryMembers.html (dostęp: 4.05.2019). 
zowania taśm filmowych. Od 2006 r. wraz z UNESCO oraz CCAAA ${ }^{41}$ przygotowuje obchody Światowego Dnia Dziedzictwa Audiowizualnego, który obchodzony jest 27 października ${ }^{42}$. Obchody mają swoje hasło przewodnie w 2018 r. brzmiało ono: "Your Story is Moving" ${ }^{43}$. FIAF wspiera także nauczanie akademickie w zakresie ochrony dziedzictwa filmowego - współpracuje m.in. $z$ Tisch School of the Arts na Uniwersytecie Nowojorskim czy z Hochschule für Technik und Wirtschaft w Berlinie ${ }^{44}$.

Federacja odgrywa niebanalną rolę $\mathrm{w}$ ochronie i popularyzacji dziedzictwa filmowego. W 2008 r., z okazji siedemdziesiątej rocznicy powołania Federacji, opublikowano manifest, któremu przyświecało hasło: „Nie wyrzucaj filmu”. Twórcy dokumentu tłumaczyli: „Nigdy nie wyrzucaj filmu, nawet jeśli myślisz, że pojawi się coś lepszego. Bez względu na to, jakie technologie pojawią się w przypadku ruchomych obrazów w przyszłości, istniejące kopie filmów łączą się z osiągnięciami i pewnikami z przeszłości”" ${ }^{45}$. Idee promowane przez FIAF będą aktualne jeszcze przez wiele lat funkcjonowania archiwów filmowych.

\section{Biliografia}

\section{Opracowania}

Bowser E., Kulper J., A handbook for film archives, Brussels 1980.

Dupin Ch., First Tango in Paris: The Birth of FIAF, 1936-1938, "Journal of Film Preservation" 2013, nr 88.

Dupin Ch., The Origins of FIAF, 1936-1938, https://www.fiafnet.org/pages/History/Originsof-FIAF.html (dostęp: 20.03.2019).

FIAF 1938-1958, https://www.fiafnet.org/images/tinyUpload/Publications/FIAF-Book shop/1958\%20FIAF\%20Brochure.pdf (dostęp: 20.03.2019).

Henrykowski M., Film jako źródło historyczne, Poznań 2000.

R. Nowicki, Międzynarodowy Kongres Archiwów Filmowych w Warszawie, „Archeion” 1956, t. 26, s. 261-263.

C. Roth, 2019 FIAF Award presented to Jean-Luc Godard, https://www.fiafnet.org/pages/ Events/2019-FIAF-Award-JLG.html (dostęp: 19.04.2019).

T. Saetervadet, FIAF Digital Projection Guide, Bruxelles 2012.

T. Saetervadet, The Advanced Projection Manual, Bruxelles 2006.

Smither R., Surowiec C.A., This Film is Dangerous - A Celebration of Nitrate Film, Bruxelles 2002.

${ }^{41}$ CCAAA - Co-ordinating Council of Audiovisual Archives Associations.

${ }^{42}$ Data ta została wybrana nieprzypadkowo - 27 października 1980 r. UNESCO ogłosiło "Recommendation for the Safeguarding and Preservation of Moving Images" - zalecenia, w których podkreślono kulturowe i historyczne znaczenie nagrań filmowych oraz zwrócono uwagę na potrzebę zachowania filmów.

${ }^{43} 2018$ World Day for Audiovisual Heritage, https://www.ccaaa.org/pages/Events/ World-Day-2018.html (dostęp: 4.05.2019).

${ }^{44}$ Academic Courses on Film Preservation, https://www.fiafnet.org/pages/Training/OtherFilm-Preservation-Courses.html (dostęp: 4.05.2019).

${ }^{45}$ FIAF Manifesto, https://www.fiafnet.org/pages/Community/FIAF-Manifesto.html (dostęp: 4.05.2019). 


\section{Źródła drukowane}

FIAF Congresses 1939 New York, 25-26 July 1939, https:/ / www.fiafnet.org/images/tinyUpload/ History/FIAF-Archives/Digitized \%20docs/Congresses/19390725\%20New\%20York\% 20 Congress_Minutes\%20Day\%201_EN.pdf (dostęp: 3.05.2019).

Minutes of the first meeting of the founder-members, 9 June 1938, Paris, Minutes of the second meeting of the founder-members, 15 June 1938, Paris, https://www.fiafnet.org/pages/History/ Digitised-Documents.html (dostęp: 20.04.2019).

Statut FIAF, http://www.fn.org.pl/public/upload/STATUT_FIAF__III26069_br_1.pdf (dostęp: 18.03.2019).

Orbanz E., Raport Film Archives in Africa, https://www.fiafnet.org/images/tinyUpload/ Training/Film-Archives-in-Africa/Film\%20Archives \%20in\%20Africa \%20-\%20Final\% 20 Report\%20English\%20-\%20July\%202015.pdf (dostęp: 17.04.2019).

\section{Strony internetowe}

About the FIAF Summer School, https://www.fiafnet.org/pages/Training/About-the-FIAFSummer-School.html (dostęp: 10.04.2019).

FBO Archive, https://www.fiafnet.org/pages/Publications/FBO-Archive.html (dostęp: 5.05.2019).

FIAF Archive: Digitized Archival Documents, https://www.fiafnet.org/pages/History/DigitisedDocuments.html (dostęp: 20.04.2019).

FIAF Associates, https://www.fiafnet.org/pages/Community/Associates.html (dostęp: 18.04.2019).

FIAF Award Recipients So Far..., https://www.fiafnet.org/pages/Events/Previous-Awards. html (dostęp: 4.05.2019).

FIAF Commissions, https://www.fiafnet.org/pages/Community/Commissions.html (dostęp: 22.04.2019).

FIAF Databases, https://www.fiafnet.org/pages/Publications/About-FIAF-Databases.html (dostęp: 10.04.2019).

FIAF Honorary Members, https://www.fiafnet.org/pages/Community/Honorary-Members. html (dostęp: 4.05.2019).

FIAF Members, https://www.fiafnet.org/pages/Community/Members.html (dostęp: 18.04.2019).

FIAFSupporters Partnership Programme, https://www.fiafnet.org/images/tinyUpload/2019/03/ FIAF-SUPPORTERS_BROCHURE-03-2019.pdf; https://www.fiafnet.org/pages/Commu nity/FIAF-Supporters.html (dostęp: 4.05.2019).

FIAF Training Outreach Programme, https://www.fiafnet.org/pages/Training/FIAF-TrainingOutreach-Programme.html (dostęp: 5.05.2019).

Filmoteka Narodowa na 72. Kongresie FIAF i 30. edycji festiwalu Il Cinema Ritrovato w Bolonii, http:/ / www.fn.org.pl/pl/news/info/61/ filmoteka-narodowa-na-72-kongresie-fiaf-i-30-edycjifestiwalu-il-cinema-ritrovato-w-bolonii.html (dostęp: 5.05.2019).

Ibermedia, http:/ / www.programaibermedia.com/el-programa/ (dostęp: 1.05.2019).

Past Events Organized or Supported by the FIAF Training \& Outreach Programme, https:/ / www.fiafnet.org/pages/Training/Past-Training-Outreach-Events.html (dostęp: 10.04.2019).

Past FIAF Confressess, https://www.fiafnet.org/pages/Events/Past-Congresses.html (dostęp: 15.04.2019).

Taller Teórico-Practico de restauración fotoquimica y digital de película cinematográfica, https:// www.fiafnet.org/images/tinyUpload/Training/Forthcoming-FIAF-training/TemarioTaller\%20UNAM-11-2015.pdf (dostęp: 1.05.2019).

FIAF Manifesto, https://www.fiafnet.org/pages/Community/FIAF-Manifesto.html (dostęp: 4.05.2019). 
Agata Łysakowska-Trzoss

\title{
"Ani jedna taśma nie może ulec zniszczeniu". Osiemdziesiąt lat działalności Międzynarodowej Federacji Archiwów Filmowych
}

\begin{abstract}
Streszczenie
W 1938 r. z inicjatywy Henriego Langois'a i Georges'a Franju z Cinémathèque Française, Franka Hensela z Reichsfilmarchiv, Johna Abbotta z Museum of Modern Art Film Library oraz Olwen Vaughan z londyńskiej National Film Library powołano do życia Fédération Internationale des Archives du Film - Międzynarodową Federację Archiwów Filmowych. Celem artykułu jest przedstawienie działalności FIAF, która w zeszłym roku obchodziła swoje osiemdziesiąte urodziny. W teście omówiono początki Federacji, jej cele i strukturę oraz działalność (włączając w to organizację warsztatów, kongresów, działalność wydawniczą i koordynowane projekty). Podkreślono także zasługi FIAF w zakresie zabezpieczania dziedzictwa filmowego oraz współpracy między archiwami. W artykule wykorzystano źródła drukowane umieszczone na stronie Federacji (takie jak sprawozdania z posiedzeń, raporty), informacje ze strony internetowej organizacji oraz literaturę dotyczącą historii filmu.
\end{abstract}

Słowa kluczowe: Międzynarodowa Federacja Archiwów Filmowych, dziedzictwo filmowe, historia filmu, materiały audiowizualne, archiwa filmowe, Henri Langois, film, kinematografia

Agata Łysakowska-Trzoss

\section{"Not a single tape can be destroyed." Eighty years of operation of the International Federation of Film Archives}

\begin{abstract}
In 1938, upon the initiative of Henry Langois and Georges Franju from Cinémathèque Française, Frank Hensel from Reichsfilmarchiv, John Abbott from the Museum of Modern Art Film Library, and Olwen Vaughan from the London National Film Library, Fédération Internationale des Archives du Film (International Federation of Film Archives) was established. The objective of the article is to present the operation of FIAF, which celebrated its 80th birthday last year. The text presents the early days of the Federation, its goals, structure and activity - including its workshops, congresses, publications, and projects. The achievements of FIAF in terms of protecting the film heritage and fostering cooperation between various archival offices are also discussed. The following sources have been used for the purposes of this paper: printed sources posted on the Federations' website (such as minutes from meetings and reports), information from the organization's website, and literature on the history of film.
\end{abstract}

Keywords: International Federation of Film Archives, film heritage, history of film, audio-visual materials, film archives, Henri Langois, film, cinematography 